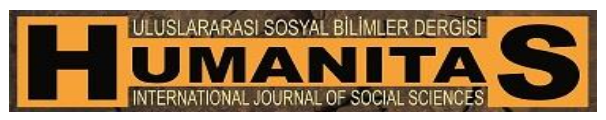

$\begin{array}{ll}\text { Humanitas, 2017; 5(9): 193-201 } & \text { http://humanitas.nku.edu.tr } \\ \text { ISSN: } 2147-088 X & \text { DOI: } \underline{10.20304 / \text { humanitas.318512 }}\end{array}$

Araştırma-İnceleme

\title{
CIVIL SOCIETY IN CONFLICT REGULATION: CYPRUS CASE
}

\section{Pinar ERKEM ${ }^{1}$}

\begin{abstract}
As a conflict regulation method, consociationalism offers stability and peace, though short-term and negative, for deeply divided societies. However, the success of consociationalism is highly doubted due to lacking long-term peace and durability. Establishment and continuation of consociational regimes mostly depend on external pressure. When the pressure vanishes, majorities tend to shift to majoritarian system or for worse, conflict can resume. This paper argues that, being only dependent on elite cooperation and on the back-up of international actors is not adequate and creates a weakness in the approach. To overcome this, domestic actors, most importantly civil societal actors, should be empowered and incorporated in the establishment of a long-term positive peace, in order the consociational system to be sustainable. Through civil society cooperation and projects, popular adoption of the system and improvement of communal relations can be realized. This argument is tested on a protracted conflict, Cyprus which has experienced power-sharing with external pressure and is still discussing it as a future solution, through evaluating the impacts of bicommunal NGO projects and outcomes of civil society initiatives. By utilizing conclusions from the case, this paper offers contribution to both procedures of consociational theory and conflict regulation in other multiethnic states.
\end{abstract}

Keywords: Conflict Regulation, Ethnic Conflict, Consociationalism, Civil Society, Cyprus.

\section{ÇATIŞMA YÖNETIMINDE SIVIL TOPLUM: KIBRIS ÖRNEĞİ}

Öz: Çatışma yönetimi modellerinden biri olan ortaklıkçı demokrasi, derin bölünmüş toplumlar için istikrar ve barış vadeder. Fakat ortaklıkçı demokrasisisteminindevamlılığı ve uzun süreli başarısına dair yaşanan örnek olaylar kaynaklı şüpheler mevcuttur. Ortaklıkçıdemokrasiye dayanan yönetim rejimlerinin kurulması ve devamlılı̆̆ 1 genel olarak dış aktörlerden gelecek baskı ve desteğe bağımlıdır. Dış aktörlerin sistemin

${ }^{1}$ Yrd. Doç. Dr., İstanbul Üniversitesi, İktisat Fakültesi, Siyaset Bilimi ve Uluslararası İlişkiler Bölümü. erkem@istanbul.edu.tr 
devamını sağlamak için desteği ve etkisi ortadan kalktığında, çatışmalı toplumdaki çoğunluk grubun, çoğunlukçu yönetim sistemine dönme eğilimi olduğu veya daha kötüsü, toplumlar-arası çatışmanın devam ettiği görülmüştür. Bu makalenin iddiası, sadece elit işbirliğine ve uluslararası aktörlerin desteğine bağımlı olmanın ortaklıkçıdemokrasi sisteminin başarısı için yeterli olmadığı ve bunun ortaklıkçı demokrasi teorisinde bir zayıflık yarattığıdır. Bunu aşabilmek ve ortaklıkçı sistemin sürdürülebilirliğini sağlayabilmek için, yerel aktörler, özellikle sivil toplum aktörleri güçlendirilmeli ve uzun dönemli barışın sağlanması çabasına dâhil edilmelidir. Sivil toplum işbirliği ve projeleri sayesinde sistemin toplum tarafından benimsenmesi sağlanabilir ve gruplar arası ilişkiler geliştirilebilir. Bu iddia, iki toplumlu STK projelerinin ve sivil toplum girişimlerinin ortaya çıkardığı sonuçlar ekseninde, uzun süreli bir çatışma olan Kıbrıs üzerinde test edilecektir. Kıbrıs dış güçlerin etkisiyle ortaklıkçı sistemi denemiştir ve hala gelecekteki çözüm planı olarak aynı sistem tartışılmaktadır. Bu örnek çalışmadan çıkarılacak sonuçlar, hem ortaklıkçı demokrasi teorisi için hem de diğer çok etnikli ülkelerdeki çatışmaların yönetimi için faydalı olacaktır.

Anahtar Sözcükler: Çatışma Yönetimi, Etnik Çatışma, Ortaklıkçı Demokrasi, Sivil Toplum, Kıbris.

\section{Introduction}

This paper rests on Galtung's negative and positive peace conceptions and tries to critically analyzeconsociational approach from the perspective of conflict settlement and transformation distinctions of conflict resolution literature. According to conflict resolution analyses, conflict settlement includes elite cooperation or elite peacemaking to reach an agreement (Ramsbotham, Woodhouse, \& Miall, 2012, s. 13).Consociational agreements can be evaluated within this framework as they are based on constitutional engineering and elite cooperation to regulate a violent conflict without addressing its structural roots. However this does not bring positive peace, which requires structural and cultural transformation to provide legitimacy and justice to the system and society, but just negative peace by ending the violent conflict (Ramsbotham, Woodhouse, \& Miall, 2012, s. 12).

As Lijphart mentioned in his 'Democracy in Plural Societies', for consociational approach "a low level of actual or potential violence", stability (which means system maintenance, civil order, legitimacy and effectiveness) and staying in democracy are priorities for plural societies (Lijphart, 1977, s. 4). However, according toGaltung, in order to establish a positive peace, what is required is overcoming the structural and cultural violence, or in other words changing the contradictions and attitudes of the parties to the conflict (Ramsbotham, Woodhouse, \& Miall, 2012, s. 12). This phase is the transformation of the conflict; it follows the agreement phase where elites make peace and electoral and constitutional reform takes place (Ramsbotham, Woodhouse, \& Miall, 2012, s. 14). 
The structural and cultural peace building phases can increase the chances of making a long-lasting, stable peace by strengthening cross-group cooperation, overcoming 'othering' by increasing contact among groups, and creating interdependency through economic cooperation. Thus, conflict transformation phase need not come after the agreement or settlement phase, but can be a part of the conflict regulation phase where consociational system is being established. Therefore, consociational theory can enrich itself with possible encompassing of civil society (Cohen \& Arato, 1994, s. preface) or grassroots activity. This is not to say that constitutional engineering or institution building is not important. On the contrary, in order to address the roots of the conflicts, which can be perceived as recognition of the basic human needs such as identity security, participation and survival, the recognition of the ethnic identities of the conflicting groups and providing security to them is of primary importance (Azar, 1990, s. 8).Nevertheless, involvement of grassroots in the peace process can facilitate reaching a peace agreement or establishment of positive peace after the agreement is realized.

\section{Consociational theory as elite based and state centered approach}

Consociational theory rests upon elite cooperation in the regulation of ethnic conflicts. The approach can be reviewed as state-centered, top-down peace building process. The main aim is to contend the violent conflict and keep the state with a functioning democracy, in which power is shared among the conflicting groups. The democracy concept used by Lijphart is not an idealized one but a "reasonable' democracy which is more synonymous with Robert Dahl's polyarchy, giving the initiative in the political processes to the elected elites (Lijphart, 1977, s. 4).Therefore, the approach is based on institutional design to share power among the elites, rather than to search for ways to establish positive peace.

WhenLijphart first discussed consociational theory, it was merely based on elite-cooperation with pre-determined rules and based on communal divisions. That version was implemented in Cyprus with 1960 Constitution and failed within three years. As it was the case in Cyprus and argued by the critics of consociational theory, elites are mostly in favor of the continuation of the conflict as they benefit from it due to the fact that they breed their politics from ethno-nationalism (Yakinthou, 2009, s. 22). Later, McGarry and O'Leary developed the theory to liberal consociationalism, extracting the given identities, relaxing the power-sharing procedure, emphasizing the role of the external actors and giving more room to individual rights. Moreover, they have criticized the theory as having limitation as being "too internalist" and "too focused on executive and legislative institutions" (McGarry \& O'Leary, Consociational Theory, Northern Ireland's Conflict and its Agreement. Part 1: What Consociationalists Can Learn from Northern Ireland, 2006, s. 63). Lately, 'complex power sharing or consociation' is a term to take place, enlarging the approach to cover more than consociational theory, such as more levels of 
governance, involvement of international actors, broader range of issues, and more approaches like power dividing and centripetalism as well as power sharing (Wolff \& Cordell, 2011, s. 307).

WhenLijphart first developed the theory, consociationalism was concerned with the within state conflicts, so the level of analyses was state level and the actors were domestic elites. With the contributions of McGarry and O'Leary, external actors entered into the scope of analyses. Therefore the actors involved expanded from domestic elite to international actors. However, as the conflicts that require a consociational solution are domestic conflicts, their regulation should not take place only in international and state levels, but should also incorporate the within-state level, which consists of civil society actors (Papagianni, 2012, s. 169).

McGarry and O'Leary made contributions on the theory to expand it to include areas that are more directly with individual lives like the design of the police forces, demilitarization, the return of exiles, management of prisoners, education reform, economic policy, promotion of language and other group rights (McGarry \& O'Leary, Consociational Theory, Northern Ireland's Conflict and its Agreement. Part 1: What Consociationalists Can Learn from Northern Ireland, 2006, s. 158). Most of these contributions have found opportunity to be tested in Northern Ireland, within an implementation of a liberal consociational regime. Moreover, establishment of a Civic Forum which provides representation to the organizations outside of conventional politics opens a channel for a wider and more comprehensive inclusion of society into the system (McGarry \& O'Leary, Consociational Theory, Northern Ireland's Conflict and its Agreement 2. What Critics of Consociation Can Learn from Northern Ireland, 2006, s. 275).In this sense, their approach can be viewed as getting related to personal or human security concepts, which will contribute to the formation of a positive peace in the post conflict societies.

\section{Incorporation of the civil society level to consociational approach}

The necessity of elite cooperation as consociational theory suggests is necessary but not sufficient for the establishment of long-lasting, positive peace. Therefore, a more comprehensive approach, which also includes civil society involvement and cooperation in the peace process, shall prove to be beneficial (Byrne, 2001, s. 330).

In order to develop a sustainable positive peace, inclusion of the civil society actors into the peace process will be empowering. In order to create a more sustainable and positive peace, local actors, NGOs, civil movements should be included in the peace process (Ramsbotham, Woodhouse, \& Miall, 2012, s. 233). Civil society activities are inclusive, enabling the inclusion of different stake holders in the society to take place in the peace process, creating interdependency among different segments of the society and also among the elites, making them understand each other's positions, building or strengthening trust and openness among the communities, which shall increase the success of 
the positive peace (Byrne, 2001, s. 179).Civil society enables ordinary people to communicate and understand each other's positions; as a result it will be easier for the political elites to compromise (O'Flynn \& Russell , 2011, s. 231). While the elites represent their group identity as 'we' and should do so in order to protect the stakes of the group, the grassroots movements can be less strict than the political actors as they are not obliged to protect any stake (Byrne, 2001, s. 329).Instead, they may be more open to create alternative methods of cooperation or build inter communal relations. So to say, they do not strictly follow 'we' character but are more interested in figuring out whom the 'other' is and how these two identities can come together. Moreover, they will facilitate the adoption of the peace process by the society, thus increasing the chances of survival of the peace (Papagianni, 2012, s. 179).

In transforming the conflicts and establishing a positive peace, the civil society can act to stimulate inter communal communication, cooperation, and awareness of the situation in a critical manner (Byrne, 2001, s. 339).The civil society actions can include cultural initiatives, reviving the common traditions that both societies share, reminding the commonness of the communities, and thus de-constructing the otherness and enmity among them. For instance, through environmental project, different segments of the society can act together for the common purpose of protecting the environment, or groups can coordinate to protect the cultural or historical heritages of their lands. School projects which increase the contact among the young members of each community can help to overcome the stereotypical perceptions. communication and information exchange in different areas shall make the conflicting communities to realize that they share similar problems or have similar interests like economic development problems, housing, social security, employment, health services, education etc (O'Flynn \& Russell , 2011, s. 226).Workshops, trainings, joint projects, reforms in education can be stated as aspects of civil society involvement in the positive peace process (Ramsbotham, Woodhouse, \& Miall, 2012, s. 235).

O'Flynn and Russell make a distinction in the civil society organization and how they shall be supported. According to them, the civil society organizations in deeply divided societies are inclusive or exclusive. The inclusive organizations are composed of members from different segments of the society or different communities, therefore their memberships are cross-cutting so they directly help to strengthen democracy. The exclusive ones have membership from only one particular community so they are socially exclusive. While both types of civil society organizations need to be supported financially or materially by the state or international community, the exclusive organizations should be supported within an umbrella organization like the Community Relations Council of Northern Ireland which acts as a platform to provide communication between the exclusivist organizations from both communities (O'Flynn \& Russell , 2011, s. 231-232).This example can be a model for Cyprus, where civil society organizations are mostly exclusive, therefore a 
common platform for them to develop communication, intercultural dialogue, mutual trust, and common projects can help building of the peace.

\section{Civil Society Cooperation in Cyprus}

The solution efforts to the Cyprus conflict have been based on consociational power-sharing among the two communities since the establishment of the Republic of 1960. However, since then the efforts have been unsuccessful as ethno-nationalism in both communities proved to be preferential to compromise (Yakinthou, 2009, s. 96). Only in 2004, one of the parties to the conflict, Turkish Cypriots, chose cooperation and compromise over the continuation of the conflict, which was due to public pressure over the long-lasting status-quo defenders from the center-right politics and against the politics of Turkey. Therefore, Cyprus case is instrumental to see the failure of leaving the incentives only to the elites and the potential positive impact of inclusion of civil society and grassroots movements to the transformation of the conflict and building a positive peace.

In Cyprus, besides the incompatibility of the stakes of each community, there is a difference of perceptions, values or relationships which are harder to reconcile (Ramsbotham, Woodhouse, \& Miall, 2012, s. 18). Particularly the security concerns over collective identity in both communities are significant, which causes misperceptions, insecurity, mistrust and harm communication among the communities (Fisher, 2013, s. 186). For instance insecurity of expression and recognition of their collective identity is detrimental in Turkish Cypriot community. Overcoming differences in perceptions or construction of identities as rival entities is not possible only through constitutional engineering. Asconsociationalism depends on elite cooperation and in Cyprus the elite politics rest on ethno-nationalism and maximalist views of communal stakes, reaching compromise becomes more difficult. Moreover, concentration of the two ethnic groups in separate geographies without any simultaneous contact with each other makes it more difficult to overcome the stereotypes and prejudices, and also to build more peaceful relations (Fisher, 2013, s. 226).At that point, civil society cooperation can be instrumental.

The impact of grassroots on a potential compromise or transformation of the conflict was apparent in the elections in Northern Cyprus before 2004 Annan Referendum (Yakinthou, 2009, s. 96). Turkish Cypriot electors changed the center-right politicians who stand for status-quo for years, into center-left politicians who promised hope for a compromise and a solution to the deadlocked conflict. Afterwards, a well-organized campaign for a positive outcome from the Annan referendum gave its result with $64 \%$ of 'yes' vote. The impact of grassroots both in the elections and referendum shows the positive impact of the inclusion of public into the politics in the conditions that they are not mobilized with maximalist, ethno-nationalist motivations. Therefore, it can be concluded that elite cooperation is a condition for the success of compromise in a consociational solution of a conflict but cannot be isolated from the positive 
impact of the grassroots or civil society (Yakinthou, 2009, s. 24). As much as the elite behavior shape the perceptions and attitudes of the public, the civil society movements can shape the politics of the elites, pushing them for a more cooperative attitude in the establishment of peace. Moreover, they can work to overcome the invisible barriers between the communities, and as a result, getting the public less vulnerable to ethno-nationalist politics of the elites and to rally for the establishment of peace.

As happened in Northern Ireland peace process, civil society actors can work to overcome stereotypes, prejudices, discrimination and the fears of people for the future solution; establish mutual understanding, communication and cooperation; create new norms, values, and a shared identity; assist peacemakers and volunteers, through trainings, mediation, problem-solving workshops, inter communal projects, dialogue groups, education and reconciliation work (Byrne, 2001, s. 339-342). An important step in creating these kind of cooperation in civil society, Secretary General of the UN proposed confidence building measures for Cyprus in 1994 for "overcoming the existing mistrust" and achieving an "overall settlement" (UN, 1994, s. 8). These measures foresaw increasing cooperation in sports, cultural events, trade, journalism, health, environment, in solving common problems like water or energy problems, developing the education policies "to promote inter communal harmony", establishing joint projects, opening Varosha and international Nicosia airport (UN, 1994, s. 15).These measures have failed to be implemented due to elite level disagreement. As Yakinthou mentions, these kinds of efforts to transform the conflict on the civil society level have failed as the focus of conflict regulation have always been on the "big problem" of compromise between the elites (Yakinthou, 2009, s. 107). However, the logic for the transformation of the conflict lays working on both levels; elite level and societal level in parallel. Without building the ground for support for peace in the societal level, the elites are not constrained by civil society; rather they can freely shape it through nationalist policies.

An example of a civil society initiative that works to overcome inter communal barriers is a socially inclusive organization that works on the restoration of archeological/historical buildings in Cyprus: The Technical Committee on Cultural Heritage. The organization is supported by both UNDP and the EU. It is headed by one Greek Cypriot and one Turkish Cypriot. The organization makes small scale to large scale projects (UNDP, 2015, s. 4). It enables cooperation between the members of the two communities in protection of cultural heritage of Cyprus. Therefore, its activities can be evaluated as collaboration for the benefit of Cyprus, regardless of ethnic identity. These kinds of projects can help to overcome the identity barriers, work as confidence building measures and support the establishment of a positive peace environment. 


\section{Conclusion}

It is important to note that the proposition of this article is not to favor centripetal approaches for conflict regulation but to develop consociational approach by including civil societal initiatives into its scope. By this way, consociational theory can offer more than institutional power sharing, overcome being state-centered and elite-centered. It can include conflict transformation and establishment of positive peace among its targets. in order to realize these aims, a multi-track diplomacy can be more fruitful, with equal emphasis on grassroots dialogue with track-III diplomacy as well as mid-level track II or elite level track-I diplomacy (Sözen, 2014, s. 4).Elite level dialogue should be supported with mid-level and grassroots inclusion to establish a sustainable peace as these different levels shall reinforce each other; particularly local level can exert pressure to the top level (Sisk, 2004, s. 259-260). Increasing contact among socially inclusive organizations and establishment of an umbrella platform for building communication among exclusive organization, like the case in Northern Ireland, can be instrumental for a sustainable peace.As a result, consociational approach can offer a more democratic model and have better chances to establish positive peace.

\section{Bibliography}

Azar, E. (1990). The Management of Protracted Social Conflict. Maryland: Dartmouth.

Byrne, S. (2001). "Consociational and Civic Society Approaches to Peacebuilding in Northern Ireland". Journal of Peace Research, Vol.38, No.3, (pp. 327-345).

Cohen, J. L., \& Arato, A. (1994). Civil Society and Political Theory. Cambridge: The MIT Press.

Fisher, R. J. (2013). "Acknowledging Basic Human Needs and adjusting the focus of the problem-solving workshop". K. Avruch, \& C. Mitchell (eds), Conflict Resolution and Human Needs (pp. 186-201). New York: Routledge.

Lijphart, A. (1977). Democracy in Plural Societies. New York: Yale University.

McGarry, J., \& O'Leary, B. (2006). "Consociational Theory, Northern Ireland's Conflict and its Agreement 2. What Critics of Consociation Can Learn from Northern Ireland". Government and Opposition, Vol.41, No.2, (pp. 249-277).

McGarry, J., \& O'Leary, B. (2006). "Consociational Theory, Northern Ireland's Conflict and its Agreement. Part 1: What Consociationalists Can Learn from Northern Ireland". Government and Opposition, Vol.41, No.1, (pp. 43-63). 
O’Flynn, I., \& Russell , D. (2011). "Deepening Democracy: The Role of Civil Society". K. Cordell, \& S. Wolff (eds), Routledge Handbook of Ethnic Conflict (pp. 225-235). New York: Routledge.

Papagianni, K. (2012). "Political engagement, mediation and the nongovernmental sector" . S. Wolff, \& C. Yakinthou (eds), Conflict Management in Divided Societies (pp. 167-184). New York: Routledge.

Ramsbotham, O., Woodhouse, T., \& Miall, H. (2012). Contemporary Conflict Resolution. Cambridge: Polity.

Sisk, T. (2004). "Peacemaking in Civil Wars: Obstacles, Options and Opportunities". U. Schneckener, \& S. Wolff (eds), Managing and Settling Ethnic Conflicts (pp. 248-270). New York: Palgrave.

Sözen, A. (2014). A New Holistic Multi-Track Peacebuilding Design for Cyprus Conflict: Blending Idealism with Pragmatism. ISA . Toronto.

UN. (1994). Report of the Secretary-General on his Mission of Good Offices in Cyprus, S/26026. New York: UN.

UNDP. (2015, 02 27). Brochure on The Technical Committee on Cultural Heritage in Cyprus (. 03 02, 2016 tarihinde UNDP in Cyprus: http://www.cy.undp.org/content/cyprus/en/home/library/partnershipfort hefuture/the-technical-committee-on-cultural-heritage--2015-html adresinden alınd 1

Wolff, S., \& Cordell, C. (2011). "Power sharing". K. Cordell, \& S. Wolff (eds), 201 Routledge Handbook of Ethnic Conflict (pp. 300-310). New York: Routledge.

Yakinthou, C. (2009). Political Settlements in Divided Societies. London: Palgrave. 